\title{
Ethics: theoretical or practical science?
}

\author{
"The problem of reconciling reality and \\ thought about reality is as old as philos= \\ ophy - we might say,. as old as thought it= \\ self ... In a certain sense the history \\ of philosophy is the record of a series of \\ attempts to make this reconciliation" \\ Quentin Lauer: Phenomenology. Its genesis and \\ prospects. New York, Harper \& Row, 1965 \\ p 5,6 .
}

"Theory and practice", the theme of the present congress, ${ }^{*}$ is definitely not a novelty. It is one of the oldest problems of mankind. The two questions "What is the case?" and "What is to be done?" have always accompanied each other like twin brothers. The problem of previous ages, viz the correct relationship between the two, is still an issue today. It happened in the history of Western thought that the pendulum swung between two extremes: some regarded the theoretical and others the practical approach as of primary import= ance. As usually happens in the case of difficult problems a third group tried to compromise with a position in between.

Today we have a noteworthy tendency of renewed em= phasis on the practical application of science in all spheres of life. Questions like the follow= ing are urgent: How do scholars treat issues pre= sented to them by society, and should they? How do scholarly results get "translated" into non-

* Referaat voorberei vir die internasionale kon= gres oor "Teorie en praktyk" wat vanaf 8-15 September 1976 te Genoa en Barcelona gehou is. 
scholarly categories? Can only academic research be justified which has an immediate relevance for society? etc.

Many leaders, in especially the Third world count= ries, today want the university to be fully com= mitted to active participation in social transfor= mation, economic modernization and the amelioration of the conditions of life and work of ordinary men and women. The university must not pursue know= ledge for its own sake. It should place emphasis on that which is immediately relevant and useful.i)

\section{Introduction}

The ordinary usage of "theory" and "practice" is marked by a sharp distinction; sometimes accent= uated by a polar opposition. This contrast is for instance, clear in the exploration of the word "theory" in the Oxford English Dictionary. "True in theory but false in practice" is a well-known idea. The common man, distrustful of intellect when not directed to immediate practical ends, speaks of theory in disparaging tones. We get the idea that "theory and practice" is an opposition of mutually exclusive elements of human life.

This distinction is used in different areas. For instance to characterize or qualify certain branch= es of sciences like, for example, theoretical and practical (or applied) paedagogics, theoretical and practical chemistry, biology etc. In exami= nations a division is often made between a theore= tical and practical part.2)

Some people do speak about "practical Philosophy" but for most of us this sounds like a contradictio in terminis. People usually think philosophers are absentminded, dwelling in the clouds, lacking the know-how of practical life. Philosophical dis= cussions can - without any loss - be dismissed to the realm of theory which has no intrinsic connec= tion with our practical problems and daily routine. The philosopher is estranged from life. In his glorious isolation he acts as an interpreter or spectator from the tribune. 
of course not all philosophers were quite satis= fied with this idea about philosophy. According to Karl Marx the time for a static interpretation of reality has passed. The real task of philos= ophy is to change reality dynamically.3) Not interpretation and knowledge are the most impor= tant, but change and action. The philosopher should not be a passive spectator from the tribune but active in the arena.

When isolated from life philosophy becomes a meaningless enterprise. When totally absorbed in practical life it is murdered because it loses its character. What exactly is the task then of philosophy?

In this paper I will confine myself to the science of Ethics as an illustration of the problem of theory and practice in philosophy. Usually Ethics is regarded as a practical science. It is the science in which (Moral) Philosophy approaches the closest towards everyday life.

Before we embark on a discussion of the problems around Ethics a brief survey of Western philosophy may be worthwile in order to ascertain how various philosophers and philosophical currents viewed the problem of theory and practice.

\section{In survey: some viewpoints throughout history}

The famous Greek philosopher, Socrates, was a prop= onent of practicalism. He was convinced that if somebody has a correct understanding of a situation, he will act morally correctly. Proper insight leads to proper action. Also, according to the Stoics, vice consisted in ignorance and good in= sight guarantees correct action. The Epicurians held the same practicalistic idea that vice is merely the result of false judgement.

These ancient practicalists, men of action, em= phasised the necessity of insight in order to be able to act correctly. By "insight", however, they did not understand scientific thought but pre-scientific, practical thinking. 
The science of Ethics, being the focal point of philosophical speculation, flourished in these different types of practicalistic philosophies.

The concept of "theory" refers to the Greek term "theoria" which originally had a cultic and relig= ious emphasis. It combines theos (god) and horăo (see), and serves to indicate an elevated cultic spectacle. (Consequently, a theoros was also the spectator of a cultic-festival.)

In this original use of the term theoria the thought which comes to the fore in time of Plato and Aristotle is already present, namely theoria as a view of reality, a meditation on form. By them the reflective capacity of man is promoted to the highest factor of elucidation. To be able to see the truth, this concept must be completely divorced from sensory representations. As a re= sult of this emphasis on the abstract concept a schism developed between philosophy and daily experience, between theory and practice.

Plato is not interested in the world of phenomena, but only in eternal, superhuman ideas. Thought is thus detached from daily experience. Theoretical knowledge is ascetic knowledge. The scholar stands estranged from the world, over against the people of daily experience - the bios theoretikus as against the bios praktikos. (Cf Socrates' narrative of the philosopher Thalos who, absorbed in thought and gazing at the stars, fell into a well!) Plato indeed admits that philosophy has a practical, forming value; but this value does not, however, negate the original alienation of theoria from daily, nalve experience: man has always still to choose either the theoretical or the practical attitude towards life.

Because for Aristotle the ideas or forms must be sought not in a supra-sensory region but rather in concrete things, his theoria brings him a little nearer to practice. He distinguishes the theoret= ical and the practical according to their separate goals: the final goal of the first is truth, and that of the second is action. The theoretical has etermal truth or principles, and the practical 
the temporary or present, in mind. Unlike Plato, Aristotle made the distinction of a three-faceted life-form: bios theoretikos, bios praktikos and bios apolaustikos. The first-mentioned is the highest form of life because within it the divine is most closely approached, and it leads thus to eudaimonia. In the second, lower, practical life-form (which includes political life) man no longer seeks eudaimonia but rather honour (time). The lowest form-which man has in common with the animals - is the bios apolaustikos, in which man seeks pleasure in order to satisfy his sensual urges.

Aristotle does not regard these three life-forms as alternatives, since man can progress from one to the other. He finds, then, an element of theoria in the two lower phases also. Even the practical man ought to reflect on what he has in mind, and the hedonist should act with due con= sideration. Against Plato, who reserves theoria as the way of life for a few adepts, it is thus for Aristotle a way of life which stands open for all men. Both however agree that the bios theoretikos is a meditation of form wherein man becomes of like form to the gods and thus reaches his highest felicity.

During the Middle Ages we encounter the important distinction between intellect and will: the first knows the truth and the last loves the good.

According to Thomas Aquino the intellect is more important than the will. Accordingly he built up an intellectualistic Ethics. According to John Duns Scotus, however, the will is the nobler facul= ty in man because of its commanding position in human activity. It even commands the intellect: we know only because we will to do so. According= ly his Ethics bears a voluntaristic tendency.

Ethics is not a theoretical but practical science.

In earlier Rationalistic philosophy we first get a strong current of scientialism (circa 1600-1700). By the term "Scientialism" I mean the exaggeration of (theoretical) reason. Adherents of this type of philosophy believed that reason could also control the doing, the praxis of man. Scientialism was 
interested in practice but primarily from a theo= rectical or scientific point of view. Sciential= istic Rationalism advocated a natural, mathematic= ally scientific ideal which could not do justice to the totality of practical experience.

In reaction against scientialism the following movement in rationalistic philosophy, called Enlightenment, dominated the scene from approximate= ly 1700-1800. This type of rationalism realized that apart from theoretical, scientific knowledge practical knowledge is as important because a large area of human knowledge does not presuppose theoretical analyses. Life is more than merely (mathematical - scientific) theory. Language, technology, society, ethical and economic life, politics, arts, education, in other words all the supra - analytical dimensions of human existence, are no longer to be approached merely scientific= ally or theoretically but in a practical manner. such practical knowledge is not necessarily the consequence of theoretical analysis. The philos= ophers of the Enlightenment realized that distor= tions will be the result when scientific theory controls practical life.

In this renewed rationalistic form of what we al= ready called practicalism in Socrates and Hellen= istic philosophy, practical, pre-scientific know= ledge is placed on the same level as scientific knowledge, even more importance is attributed to it. There is however a marked difference from ancient practicalism. Socratic practicalism simp= ly used to mean good (practical) insight which guaranteed the correct action. Now it acquires a rationalistic tone. The insight is now a practic= al a-priori, the practical reason. In the eight= eenth century there was a great desire to apply the a-priori principles of rationalism concretely, in all areas of life. The broader view of the "Aufklärung" philosophers, compared with the scientalists of the seventeenth century, was much more influential and culturally more significant. Practicalistic rationalism spread far and wide. Ethics became so important that we may speak of moralism amongst some of these kinds of philos= ophers. 
The third current in earlier rationalistic philos= ophy, called Idealism, was an attempt to reconcile the scientialistic and practicalistic forms of rationalism by accepting one reason with a theo= retical and practical "compartment".

I Kant (1724-1804), the world famous philosopher from Köningsberg, was the father of this type of philosophy. In his most significant works Critique of Pure Reason, Critique of Practical Reason and Critique of Judgment he discussed the domains of theoretical reason, practical reason and the com= bination of theoretical and practical "ratio".

Apart from these main works some of his smaller works provide interesting material about his views on theory and practice, for instance Was heisst: sich im denken orientieren? (Immanuel Kant Werke in Zehn Bänden by Wilhelm Weischedel, Vol 5, p 265-283) and especially his über den Gemeinspruch: Das mag in der Theorie richtig sein, taugt aber nicht für die Praxis of 1793 (Immonuel Kont Werke in Zehn Bänden by wilhelm Weischedel, Vol 9, p 125-172). In this work it is clear that the priority kant ascribed to the prac= tical above the theoretical reason does not imply priority of practice above theory. Kant is clear= ly not in agreement with the opposition between theory and practice. He makes the interesting statement that, if a theory does not work in prac= tice, the fault is not necessarily the theory but it may be that the scientist did not have sufficient theoretical knowledge to apply it suc= cessfully in practice!

The period of late rationalism (roughly 19 th cen= tury) consists of three currents which resemble the three stages of early rationalism: first the scientialism of the positivists, secondly the practicalism of the neo-positivists and thirdly a movement which tried to reconcile the previous two, viz neo-idealism. In a different form the old problem of theory and practice returned once again in late rationalism.

In the 19 th century already the ideas of men like $F$ Nietzsche and $S$ Kierkegaard had heralded the end of the "Age of Reason". Irrationalism became one 
of the leading philosophic currents in the twen= tieth century. As the name indicates it is $z \mathrm{re}=$ action to rationalism, anti-rationalism. Irra= tionalism, however, is not a philosophy void of reason. Irrasionalistic philosophers still accept= ed science but the signifance of reason is releg= ated to a rather small area. Reason and theoret= ical knowledge is dethroned but not put out of commission altogether. Depending upon the type of irrationalism a certain domain of human life (the irrational) escapes the scope of reason. Reality is not merely a rational reality, all of life is not causally determinded or scientifically predict= able.

Irrationalism is a philosophy of practice. Though at a distance, this type of philosophy follows Immanuel Kant's philosophy. His division of reason into a theoretical and practical reason was intend= ed to make room for the practical facets of life, $\mathrm{e} g$ the freedom and ethical responsibility of man. Man should not bow under theoretical reason in the moral decisions to be made. Ethical life proceeds from an origin, though still a rational one of its own. Irrationalism went further on the ame road and substituted for Kant's practical reason the practical free act - not regulated by reason. It abandoned the idea of a universal rational-moral law and replaced it with human autonomy and creat= ive freedom. 4 )

Pragmatism, one twig on the branch of irrational= ism (the two other irrationalistic currents are "Lebensphilosophie" and Existentialism) proclaimed that truth cannot be expressed merely in theoretic concepts. Theory is mea.ringful only wiien it p:u= motes practical usefulness. An idea is not true until it becomes true in a prastical situation.

In reviewing the history of Westcrn thought it is clear that whenever emphasis was placed on the socalled practical side of human life iriterest in ethical problems awakened. It seems to be a fixed idea throughout Western phjlosophy that Ethics has as its definite field of investigation the practi= cal conduct of man. 
3. In critique: traditional viewpoints about Ethics

The very strong tradition of regarding the prac= tical as the field of study of Ethics is still to= day clearly reflected in most contemporary defini= tions of this discipline. A choice at random will prove this.

+ Mackenzie, A manual of ethics:

"Ethics may be defined as the study of what is right of good in conduct. It is the general theory of conduct and considers the actions of human beings with reference to their rightness or wrongness, their tendency to good or evil... Ethics ... we may say, discusses men's habits and customs, or in other words their characters, the principles on which they habitually act, and considers what it is that constitutes the rightness or wrongness of those principles, the good and evil of those habits."

+ Cronin, Science of ethics:

"Ethics may be defined as the science of human conduct as according with human reason and directed by reason towards man's natural, final end."

+ Carritt in The theory of morals. An introductz.n to ethical Philosophy concentrates his study of Ethics on what duty is:

"What then is the nature and authority of duty? What are our duties? What makes it right?"

+ Frankena, Ethics:

"Ethics is the systematic study of human actions from the point of view of their rightness or wrongness as means for the achievement of ulti= mate happiness."

From these definitions of Ethics the following de= ductions can be made about the subject matter of this science:

1. Practical life.

2. The human being (his character, habits, cuties, virtues, pleasures, happiness and fins l end).

3. Human conduct. 
4. Human conduct according to princıples.

5. Good and bad conduct or judgements.

My main point of criticism is that the traditional idea of the praxis as the field of study of Ethics misled moral philosophers to assign a far too broad spectrum of life to investigation by the science of Ethics.

If we assume (more or less in the line of the Western tradition) the practical side of life to be the non-scientific (in the sense of pre-scien= tific) or non-theoretical part of life, it is necessary to notice that the concept of a "prac= tical life" is a very vague one. Practical life displays a rich diversity. It consists of a variety of at least fifteen different aspects: ${ }^{5}$; the arithmetic or numerical (discrete quantity), spatial (continuous extension), kinematic (motion), physical (energy), biotic (vitality/life), sensi= tive or psychic (feeling), logical (distinction), historical (formative power), lingual (symbolic meaning), social (intercourse), economic (frugal= ity in managing scarce goods), aesthetic (harmonyh juridical (retribution), moral (troth) and pistic (faith or assurance). The ethical or moral is only one aspect of multi-dimensional reality.

If Ethics has the whole (practical) life as its field of investigation the implication is that it is a universal science, a hegemony of this science over all the other disciplines which are either merely subdivisions of this all - encompassing Ethics or have no right of independent existance at all.

My contention is that Ethics is a special science which studies a specific facet of reality, viz the moral aspects. The traditional concepts about the ethical (as identical with the practical) are far too broad. The whole of (practical) reality can not be viewed through the keyhole of the ethical.5)

Lacking clear distinctions the "ethical box" is given any size, shape and content. Ethics is not clearly distinguished from, for instance, Anthropology (Bingswanger), Cultural Philosophy 
(Scheler), Paedagogy (Bollnow), Political Science (Brunner), Sociology (Neurath and De Rougemont), Dogmatics (Barth), Linguistics (Hare), Psychology (Schlick and Spranger), Ecclesiology (Althaus and Heim), etc.

Against this background it will be clear why I cannot accept the five viewpoints about Ethics listed above.

1. The origin of the distinction "theoretical/ rational - ethical" should be obvious from our historical survey of Western Thought. It is de= rived from the ancient distinction between theory and practice. Man, however, is not merely a rational - ethical being but his existence displays a variety of aspects. Apart from the rational (or logical) and moral (or ethical) facets, we disting= uished above at least thirteen other different as= pects. Therefore it would be just as arbitrary and incomplete a definition to call man an historicolingual being. We should be on our guard against those merely one- and two-dimentional viewpoints about man in which the history of Western thought abounds (Cf homo orans, homo economicus, homo viator and today l'homme révoltè).

2. For the same reason Ethics cannot have as field of study the habits, character, duties, virtues etc of the human being. Man's habits, character etc may have an ethical aspect which can be the subject matter of this science. Habits, character and so forth as such, however, should not be regarded as its field of study. Economic habits, religions duties, social virtues are something different from ethical habits, duties etc and should be stud= ied in the respective sciences, viz Economics, Theology and Sociology. If we do not draw a clear line of demarcation the consequence will be that there is no difference whatsoever between Ethics and Anthropology.

3. The same remarks are applicable to the idea that human conduct should be ascribed to Ethics. 7$\}$ When Ethics studies ethically qualified conduct, then we would agree. It can by no means have as field of study the whole range of human conduct 
and activity. Man is always busy in a variety of at least fifteen different activities.

Some moral philosophers have introduced a sup= plementary criterion: not all human conduct, but specifically human conduct in relation to one's fel= Zowmen. 8) This is a slight improvement - because it excludes, for instance, one's conduct in rela= tion to God which, to my mind, is definitely not of a moral but a religious nature. Still "conduct in human relationships" is much too wide. The human being can act in biological, psychical, juridical, lingual, and many more relationships towards his fellowmen. All these types of activi= ty should be studied by Biology, Psychology, and the Sciences of Law (Jurisprudence) and Linguis= tics. Otherwise Ethics could not be safeguarded against imperialism in the field of science. Because many theologians also accepted the idea of Ethics being the study of human conduct in rela= tionships to one's fellowmen, and because they divided the Decalogue into two parts (the first four and last six commandments) of which the second regulates human relationships, they also considered the so-called second table of the Law of God as part of their Ethical studies. I can= not agree with this division between religious laws (first table) and ethical commandments (second table). All ten commandments of the Decalogue are laws of the covenant, religious in character. Man's relation towards his fellowmen is also part of his religion. Again: these commandments also have an ethical aspect but they are definitely not purely ethical as such.

4. Yet another view about this much disputed science is that it should confine itself to the principles of human conduct. (As illustrated in the survey of history the Rationalists emphasised a-priori practical moral principles. Practical conduct should be directed by good insight.) The idea that Ethics has the monopoly of studying matters of normativity is wrong. Many moralists today are of the opinion that all questions about what one ought to do automatically are ethical in nature. Man, however, ought to do many things: 
promote justice, love his neighbour, serve his country, etc.

There is no such a thing as an "universal ought". Upon investigation this so-called universal ethic= al "ought" falls apart into various "oughts". An ought is not as such necessarily ethical.9)

Because all the abovementioned aspects of life are subjected each to its own norms or principles we get a logical ought, an historical ought, a ingual, social, economic, esthetic and ethical (moral) ought. "Ought" always bears a qualifica= tion.

Ethics should also study, apart from ethical phen= omena, the ethical norms which indicate what man ought to do, how to act in this specific facet of life. I may add here that the contrast between description - evaluation is untenable. It is im= possible to study ethical (or any other human) "facts" apart from values. (Values viewed as the answers or reactions of the human being to the norms.) Every human act reveals a positive or negative answer to the norms in a certain domain of life, be it ethical, juridical or economical. Ethics cannot be a merely descriptive science with= out any prescriptions because as a human being one knowlingly or unknowingly passes certain judgements which cannot be neutral. In the light of the above the old theological distinction between - Dogmatics and Ethics, viz that the first should study the norma credendorum (norms of belief) or credenda and the last the norma agendomum (norms of conduct) or facienda is also unacceptable.10)

5. The current idea about what ought to be done brings us to the next, viz that Ethics has to do with good and bad, right and wrong in conduct. My reply in this case could be predicted by this time. I am repeating - monotonously, I agree - that good and bad are not specific ethical concepts. One may speak about a good or bad piece of art, good or bad biological or psychical conditions, a good or bad usage of language, good and bad judgements, and so forth. Because after original sin the good - had distinction goes right through the whole cosmos, we get economical or uneconomical, logical or 
illogical, moral and immoral behaviour. Good and evil bear different meanings dependent on the area of concern. To compose a bad (grammatically in= correct) sentence or to behave socially incorrect= ly is not to be guilty of an immoral wet. Ethics should confine itself to the morally good and bad.

It is important to distinguish here between the immoral and the amoral. The field of study of Ethics is the moral aspect of life including the morally good as well as the immoral (ethically bad). Its field of study is not the a-moral (nonethical), in other words the economically, juridic= ally etc good and bad.

\section{In Outline: a new perspective}

In this concluding perspective I will first make a few comments about the relationship between theory and practice in order to be able, in the second place, to add something about ethics as special science.

\subsection{Theory and practice}

There is a difference between a mother's knowledge about the illness of her sick baby and the diag= nosis of the medical professor. The judgement of a woman buying expensive cosmetics and the econom= ist's reflection on the buying habits of women differ. The same difference exists between a mother's advice to her daughter and the ethicist's reflection on the ethical aspect of her advice. This difference is the difference between prescientific (if you wish "practical") knowledge and theoretical, scientific knowledge.

We should clearly distinguish these two types of human knowledge but must never see them in opposi= tion to each other as has happened throughout the history of Western thought and as is still the case in ordinary language. 11) Usually pre-scient= ific knowledge is regarded as practical and scient= ific knowledge as impractical. The truth is that both kinds of knowledge are practical. The differ= ence between the professor of medicine and the 
medical doctor is not that the one is a theorist and the other a practitioner, but rather that it is the practice of the former to investigate cer= tain aspects of human illness and to impart the results of these investigations to the students who wish to become doctors, whereas it is the practice of the latter to use the knowledge thus acquired to cure people in whom these aspects appear to be malfunctioning. The activities of both are very practical even though one man is theoretical and the other is not.

Not theory is opposed to practice, but impractical to practical. It is therefore important to distin= quish between practical (and impractical) activit= ies of a theoretical, and such activities of a nontheoretical nature. What is isually considered as a practical activity can be very impractical, and at the same time a theoretical activity can be very practical:

The pre-scientific is not unscientific but nonscientific. It is of another kind than scientific knowledge and therefore would be judged by other standards than those of science. Consequently there is no difference in value between scientific and pre-scientific.12)

The difference between those two kinds of know= ledge is that pre-scientific knowledge comes earlier. Naive experience (from Latin nativum, meaning "original") precedes science, it is a necessary condition for the acquisition of theoret= ical knowledge. The fact that pre-theoretical knowledge is less complicated than theoretical knowledge does not therefore imply that the former is of less value.

These two types of knowledge are not mutually ex= clusive but mutually complementary. Practical pre-scientific knowledge (including one's view of life and world) directs one's scientific endeavours while scientific knowledge may help us to attain a deeper insight into our daily "practical" activit= ies.

Therefore our view of life (or philosophy, as the 
theoretical explication of our "Weltanschauung") is not isolated from our daily walk of life but part of it.13) our walk ("lewenswandel") is closely bound to our philosophy of life ("lewens= visie") since the serious walker looks about him and orientates himself as he goes. He knows both his destination and the various stages of his journey as he reaches them.

I reject scientialism in which too great a role has been assigned in life to scientia, science. Scientism is not the same as science. It is a conviction of faith about the place of science in the whole of our life. The scientistic (not scientific) thinker has wrongly identified all proper knowledge with scientific knowledge.14) For example: to speak of the sun's going down is not an unscientific or primitive statement because according to modern science there is no (beautiful) sunset!

Recapitilating on what has already been said about reality consisting of at least fifteen different modalities or aspects, I have the following con= cluding remarks. Firstly: In the distinction theory - practice the theoretical (Logical) is contrasted with the rest of reality. From the pre= ceding it will be clear now that this is not necessary. There is no opposition between the theoretical and "the rest". Secondly: the "rest" is usually viewed under a single denominator, namely the ethical/moral. It will be as obvious now that to designate all a-theoretical as prac= tical or ethical is not correct. Reality reveals a richness not to be captured in a single concept.

\subsection{The essence of the ethical}

In the third part of this paper I was busy peeling an onion so to speak. One layer after another was rejected (practice, human relationships, conduct, ought, good and bad) because it was not the kernel or nucleus of the ethical. If the ethical cannot be identified with the practical, conduct etc, what then? Is the essence loyalty, respect, re= sponsibility, (5) solidarity, 16) love?l7) 
The question about the kernel is not a speculative but a very practical, urgent question as it will enable us to draw a line of demarcation between Ethics and all the other special sciences as far as their fields of investigation are concerned. Although it is true that reality has an ethical aspect, it is very difficult to describe and im= possible to define absolutely surely its kernel moment. This is due to the a-logical, irreducible nature of the kernel moments of all aspects of reality. Science has to recognize its impotence to grasp exactly what the "essence" (not in the sense of law) of the ethical is.

The best definition thusfar, I think is that of troth. 18) "Troth is an old English term for truth, faithfulness, loyalty, and honesty. The single word troth captures the nuances of trust, reliabil= ity, stability, scrupulousness, ingenuousness, authenticity, integrity, and fidelity. To be fic= kle, capricious, unreliable, shifty, whimsical, disloyal, rootless, perfidious is to be anything but trothful."19) Troth is a facet of God's many-sided call to love. Just as thrift is the economic expression, so justice is the juridic ex= pression and troth the moral expression of the central commandment of love.

Whereas the state is qualified by the juridical, the business enterprise by the economic and the church by the pistical aspect, marriage, family and friendship relationships are qualified by troth or fidelity. of course marriage, family and friendship also have economic, lingual, esthetical, social etc facets when analyzed philosophically but the ethical is the pilot of qualifying func= tion. The science of Ethics will therefore have as its field of study these three societal rela= tionships especially. (Of course also other sciences may investigate marriage and family rela= tions from their respective vantage points.) This does not imply that nothing else should be the subject matter of Ethics. Because the state, school, church, university and sportsclub also have ethical facets these may also be investigated by the ethicist. 
Time and space do not permit me to work out in details this new perspective on the science of ethics. I prefer to leave it for the moment in its embryo stage to provide some time for discus= sion.

I hope my main contention is clear.

Ethics is not the dull hobby of an even duller academician. It is an important science. Because it is a science - and to my mind a science with a limited scope - it is not void of meaning but full of practical relevance.

Philosophical, abstract, theoretical reflection is not a racking of the brains about matters which never trouble the average man. In the previous pages Philosophy helped us to attain more clarity about different issues especially the vexing prob= lem of theory and practice. We must philosophize or ... fossilize. Aristotle once said: "Whether we will philosophize, or whether we won't philos= ophize, we must philosophize."20)

B $J$ van der walt

PU for CHE 
RE FERENCES

1. Cf the different papers delivered at a conference on "The role of universities in Southern Africa" organized by the "Centre for Intergroup Studies" at the Univer-ity of Cape Town, Rondebosch 7700, South Africa. Especially these of A Wandira (Swaziland), $T$ G zengeni (Rhodesia) and $W M$ Kwagare (South Africa).

2. Cf Chapter I of W Young, Foundations of Theory. Nutley, N J Craig Press, 1967 on the histortcal backgrounds of the dist= inction between theory and practice. Also R Elsler's "Wörterbuch der philooophischen Begriffe III, Berlin, S Mittler Sohn, 1910 sub voce "Theorie" (p 1506-7).

3. Cf, his Thesen über Feuerbach, no 11. Cf in this connection also $J$ Habermas, Theory and practice (translated by J Viertel). London, Heinemann, 1974. Interesting reading about the relation between philosophy and practical life is offered by $P$ G W du Plessis, Praktiese Filosofie. Bulletin van die Suid-Afrikaconse Vereniging vir die bevordering van Christelike Weten= skop, nr 48/49:18-26, April/June 1976.

4. The Existentialistic viewpoints about ethics is discussed by $P G W$ du Plessis in the following publications: Grepe ult die eksistensialistiese etlek. Koers, 25(3) 207-14, Dec. 1957; Enkele gesigspunte in die huidige etiek. Nederduit Gereformeerde Teologieae Tydskmif, 1 (3):48 et seq, Jun 1960; Etiese aard en etiese norm. Philosophia Reformata, 28:170-96, 1963 and Opskorting van die etiese? (1966).

5. Cf L Kalsbeek, Contours of a Christicn Philosophy. Toronto, Wedge Publishing Foundation, 1975. p 100 .

6. Cf P G W du Plessis: Aspekte van praktikalisme en etisisme. Iets oor die gelykskakeling van die praktiese en die etiese lewe. Correspondentiebladen van de Vereniging voor Calvinistische Wijsbegeerte, 22:18-22, Dec 1958.

7. Cf P G w du Plessis, op cit, p 20 .

8. According to $s$ p van der walt not only the relation to one's fellowmen but also the relation towards the rest of creation (plants, animals etc) and even the relationship to God is the field of investigation of Ethics. Cf his essay Etiek Wetenskap van relasies, In Truth and reality (1971), p 22233.

9. Cf P G W du Plessis, Philosophia Refomata, 28:188-90, 1963; $\mathrm{J}$ H olthuls: Facts, values and ethies (1968), 200-1; J H Ol= thuis: Towards reconstruction in ethics: a proposal. $R E S$ Theological Bulletin, 2(4):6-8 Dec 1974 .

10. Cf olthuis, Towards reconstruction in ethics, $p 8$.

11. Cf J A L Taljaard, "Teorle en Praktyk" Perspektief (Potchef= stroom), l(3):28-41 October 1962 and $J w$ Tunderman, 
"Wijsbegeerte en Levenspractijk", In $\mathrm{H} J \& \mathrm{~J} M$ Spier, Wijsbegeerte en Levenspractijk. Kampen, Kok, 1948, p 7-24.

2. Cf The essay of H E Runner: "Scientific and Pre-Scientific" In Christian Perspectives 1961. Hamilton, Ontario, Guardian Pub Co, 1961, p 11-52.

3. Cf K J Popma: Levensbeschouning $V$. Amsterdam, Buijten \& Schipperheijn, 1962, p 39.

4. Cf Runner, op cit, p 41 .

5. The viewpoints of Dietrich Bonhoeffer and Richard Niebuhr

6. Cf F N von Meyenfeldt, The meaning of ethos (1974), p 38, 57.

7. According to most Calvinistic philosophers the root or nuclear-meaning of the ethical is love. Cf $H$ Dooyeweerd A new critique of theoretical thought Vol I, P 48 and II, 152-59 ("temporal relationships of love"); H G Stoker: Teologie= se, wysgerige en vakwetenskaplike Etiek, In Oorsprong en Rlgting I (1967) p 227 ("persoonsliefde"); 'n Wysgerige benadering van die sedelike, In oorsprong en Rigting I (1967)，250-51 ("persoonsbehartiging"); Wysbegeerte van die Skeppingsidee, In Oorsprong en Rigting II (1970), p 285 ("Persoonsbehartiging ... d $w s$ persoonsliefde") and Beginsels en metodes in die wetenskap (1969), p 165 ("persoon-, m a w self- en naasteliefde"); A Troost, Casuistiek en Situatie - Ethiek, (1958), p 40,48, 110, 116, 345 ("naaste= liefde"); H van Riessen, Wijsbegeente (1970), p 182 and 188 ("liefde"); E A Venter, Wysgerige Temas ( $\mathrm{s}$ ), p 35-37 ("persoonlikheidsliefde" d $w$ s "self-en naasteliefde").

18. Cf J H Olthuis, Facts, Values and Ethics. (1968), p 199.

19. J H olthuis, I pledge you my troth (1975), p 21. We find olthuis' viewpoint also in the publications of predecessors like D H Th Vollenhoven, Isagoogè Philosophiae, (1943, reprint 1967), P 24; J A L Taljaard, Die mens, die liefde en die sedelike, Koers, 23(6):19, 1956 and K J Popma, Inleiding in de Wijsbegeerte (1956), p 17.

20. J W Tunderman, op cit, p 22 correctly stated: "Wie ... meent, dat de practijk zelf-genoegzaam is en van opvating is, dat hij zich met een glimlach van alle wijsgerige be= zinning kan afkeren, zal daarmede blijk geven, zonder het te weten, slachtoffer te zijn van een bepaalde wijsgerige opvatting $n l$ het practicistische". 
Dooyeweerd, $\mathrm{H}$, A new critique of theoretical thought. Vol II. Amsterdam/Philadelphia, 1! J Paris/The Presbyterian and Reformed Pub Co, 1955.

Du Plessis, P G W, Aspekte van praktikalisme en etisisme. Iets oor die gelykskakeling tussen die praktiese en die etiese lewe. Correspondentiebladen van de vereniging voor Calvinistischt Wijsbegeerte. 22:18-22, Dec 1958 .

Du Plessis, P G W, Enkele gesigspunte in die huidigo utiek. Nederduits Geref Teol Tydskrif 1(3):48 et seq, Jun 1960 .

Du Plessis, P G W, Etiese aard en etiese norm. Philosophin, Reformata 28:170-96, 1963. (Summary on P 195-196)

Du Plessis, P G W, Grepe vit die eksistensialistiese etiek. Koers 25(3); 207-214, Dec 1957.

Du Plessis, P G W, Opskorting van die etiese? Die etiese behore by $M$ Heidegger, $K$ Jaspers, J-P Sartre en $S$ de Beauvoir. (With summary) Potchefstroom, Pro Rege-Pers, 1966.

Duvenage, $\mathrm{B}$, Veranderende norme of ' $\mathrm{n}$ pleidoot vir 'n Calvinis= tiese Deontologie. (In Besinning en Uitsig. Potchefstroom, PU vir CHO, 1971.) p 93-112.

Kalsbeek, L, Contours of a Christian Philosophy (ed by B S J zylstra) Toronto, Wedge Publishing Foundation, 1975.

olthuis, J H, Facts, values and ethics. A confrontation with twentieth century British moral philosophy in particular G E Moore. Assen, Van Gorcum \& Co, 1968.

olthuis, J H, I pledge you my troth. A Christian view of marriage, family and frlendship. New York, Harper Row, 1975.

olthuis, J H, Towards a reconstruction in ethics: a proposal. Reformed Ecumenical Synod Theological Bulletin, 2(4), Dec 1974.

Popma, $\mathrm{K} \mathrm{J}$, Inleiding in de Wijsbegeerte. Kampen, Kok, 1956.

Stoker, H G, Beginsels en metodes in die wetenskap. Johannes= burg, Boekhandel de Jong, 1969.

Stoker, H G, Teologiese, wysgerige en vakwetenskaplike etiek In Oorsprong en Rigting I, Kaapstad, Tafelberg Uitgewers, 1967. p 23-230.

Stoker, H G, Die Wysbegeerte van die Skeppingsidee. In Oorsprong en Rigting II. Kaapstad, Tafelberg U1tgewers, 1970. p 202-330.

stoker, H G, 'n wysgerige benadering van die sedelike. In oor= sprong en Rigting $I$. Kaapstad, Tafelberg Uitgewers, 1967. p $231-283$.

Taljaard, J A L, Die mens, die liefde en die sedelike. Koers $23(6): 295-318$, June 1956 .

Troost, A, Casuistiek en situatie-Ethiek. Utrecht, Drukkerij Libertag, 1958.

Van der walt, S P, Etlek-Wetenskap van relasies. In Truth and reality. Philosophical perspectives on reality dedicated to prof H G Stoker. Braamfontein, De Jong's Bookshop, 1971. 
p 222-233.

Van Riessen, H, Wijsbegeerte. Kampen, Kok, 1970.

Venter, E A, Etiek: mens en medemens. (In Wysgerige Temas. Bloemfontein, SACUM, s j) p 35-39.

Vollenhoven, D H Th, Isagoogè Philosophiae. Amsterdam, Filoso= fisch Instituut de Vrije Universiteit, 1967.

Von Meyenfeldt, F H The meaning of ethos. (Christian Perspec= tives Series, 1974). Hamilton, Ontario, ARSS, 1974. 